\title{
Fathering a child after childhood cancer treatments
}

\author{
Joana B. Serrano · Andreas Meißner · Ans M. M. van Pelt · Callista L. Mulder
}

Accepted: 12 January 2022 / Published online: 7 February 2022

(c) The Author(s) 2022

\begin{abstract}
Among many deleterious ramifications of oncological treatments, there is permanent male infertility due to the damage to spermatogonial stem cells (SSC) in the testes after chemotherapy or irradiation. For those patients that cannot produce sperm before cancer treatment, because of prepubertal age, there are no clinical options available to father a child. To preserve fertility in childhood cancer patients, freezing of a testis biopsy is already offered before cancer treatment, while fertility treatment options using this biopsy are still under development, including spermatogonial stem cell transplantation (SSCT). SSCT requires isolation and in vitro propagation of spermatogonial stem cells from the cryopreserved biopsy, followed by autologous transplantation back to the adult cancer survivor. Given the implications of this potential stem cell therapy to recipients, their partners, and future offspring, we here aim to thoroughly appraise the state-of-the-art of SSCT focussing on safety for both patient and his future children.
\end{abstract}

Keywords chemotherapy - fertility preservation · infertility $\cdot$ testis $\cdot$ spermatogonial stem cell transplantation

J. B. Serrano, MSc · Prof. Dr. A. M. M. van Pelt, PhD .

Dr. C. L. Mulder, $\mathrm{PhD}(\varpi)$

Reproductive Biology Laboratory, Center for Reproductive

Medicine, Amsterdam Reproduction and Development research institute, University of Amsterdam, Amsterdam UMC, Amsterdam, The Netherlands

c.l.mulder@amsterdamumc.nl

\section{A. Meißner, $\mathrm{MD}, \mathrm{PhD}$}

Center for Reproductive Medicine, Amsterdam UMC, Amsterdam Reproduction and Development research institute, Department of Urology, University of Amsterdam, Amsterdam UMC, Amsterdam, The Netherlands

\section{Vaderschap na behandeling van kinderkanker}

Samenvatting Chemotherapie en bestraling, veelgebruikte kankerbehandelingen, kunnen leiden tot mannelijke infertiliteit. Naast vernietiging van kankercellen, worden namelijk ook de spermatogoniale stamcellen (SSC's), gelegen in de testes, beschadigd. Voor jonge, prepuberale patiënten bij wie de spermatogenese nog niet op gang is gekomen, is er momenteel geen klinische oplossing om biologisch vader te worden. Hoewel fertiliteitsbehandelingen, zoals spermatogoniale stamceltransplantatie (SSCT), nog steeds in ontwikkeling zijn, wordt voor het waarborgen van fertiliteit van deze jongens het invriezen van een testisbiopt aangeboden voorafgaand aan de kankerbehandeling. Voor SSCT moeten SSC's uit het ingevroren testisweefsel worden geïsoleerd en vermeerderd in vitro waarna deze teruggeplaatst kunnen worden in de testis van de intussen volwassen geworden man. Gezien de mogelijke consequenties van deze behandeling voor de ontvanger en zijn nageslacht, zullen wij hier een volledig overzicht geven van de huidige status van SSCT met een belangrijke focus op de veiligheid voor zowel de patiënt als zijn toekomstige kinderen.

Trefwoorden chemotherapie $\cdot$ fertiliteitspreservatie onvruchtbaarheid $\cdot$ testis $\cdot$ spermatogoniale stamceltransplantatie

\section{Introduction}

Fulfilling the desire for genetically related children in paediatric cancer survivors and those that have received stem cell therapy to cure benign haematological disease is hampered by the long-lasting effect of the gonadotoxicity of many treatments $[1,2]$. Ideally these toxicities should be addressed and managed by 
anticipating the solutions required to alleviate these late effects. It is imperative to provide the best possible long-term care in order to improve quality of life for these patients after the cancer is cured [3]. Every year, over 400 children (0 to 14 years) are diagnosed with cancer in the Netherlands [4]. However, with the improvement of cancer treatment and care, survival rates have also increased steadily. In fact, mortality rates have plummeted from 238 cases in 1970, to 61 in 2016 [5]. Therefore, there is an increasing group of paediatric cancer survivors that have equal desires as their age-peers for a family of their own.

Fertility preservation in male childhood cancer patients should be ideally considered before initiating gonadotoxic treatments, as the impact of chemotherapeutic agents and radiotherapy [2] can cause spermatogenic impairment, which might not be re-established in the long-term. According to the last international guidelines it is highly recommended to counsel all patients that need to undergo gonadotoxic treatment regarding their risk of infertility [3]. Whereas adult and (post-) pubertal cancer patients have the possibility to cryopreserve semen before gonadotoxic therapies, prepubertal boys do not produce sperm as their testes are still immature. However, already at birth, the testes contain spermatogonial stem cells (SSCs) that have the capacity to differentiate into sperm after puberty. Therefore, a testicular biopsy taken prior to gonadotoxic treatment may provide a means to safeguard the future fertility for prepubertal boys ([6]; Fig. 1). This entails a multidisciplinary informed approach from all stakeholders (health-care providers, patients, and their families) to counsel and initiate cryopreservation of male gonad tissue before the cancer or benign hematologic disease are treated with gonadotoxic therapeutics [2, 3]. Currently, there are fertility preservation programs implemented globally offering testicular biopsies to childhood cancer patients [2]. However, a fertility treatment to help them become a father using this biopsy is not yet available.

Present medically assisted reproduction (MAR) technologies, including in vitro fertilization (IVF) and intracytoplasmic sperm injection (ICSI) together with surgical sperm retrieval by means of testicular sperm extraction (TESE) or microsurgical sperm aspiration (MESA), rely on the collection and in vitro manipulation of mature gametes (i.e. oocytes and sperm) to achieve a live birth. This means that in the current clinical setting prepubertal testicular biopsies cannot be used since SSCs have not differentiated yet into sperm. Currently, several SSC-based fertility treatments to restore infertility due to gonadotoxic treatment are under investigation. Spermatogonial stem cell transplantation (SSCT) is one of the proposed methods to restore fertility in childhood cancer survivors, which is the only method allowing natural conception (Fig. 1). Multiple animal models have proven the effectiveness of this novel fertility treatment $[7,8]$. Apart from feasibility, studies on safety
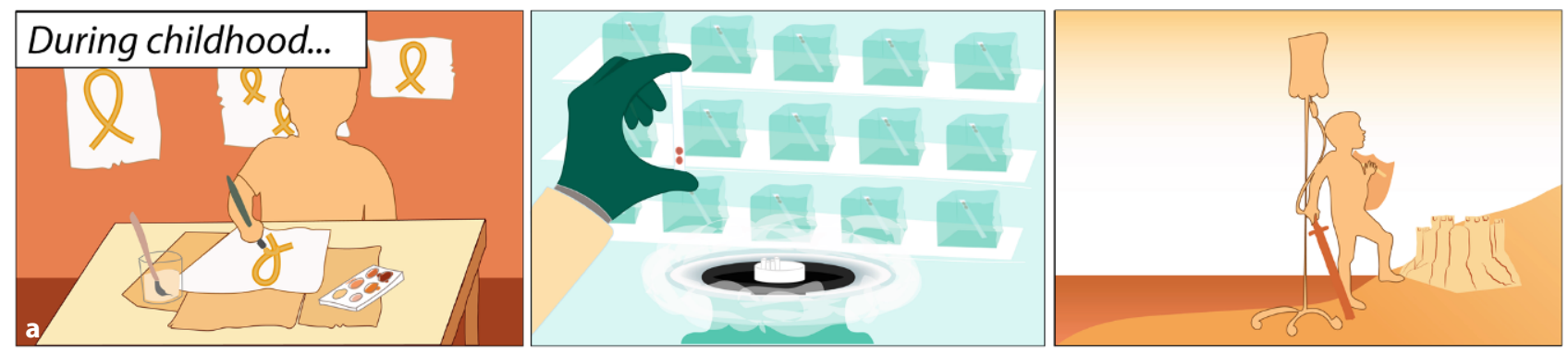
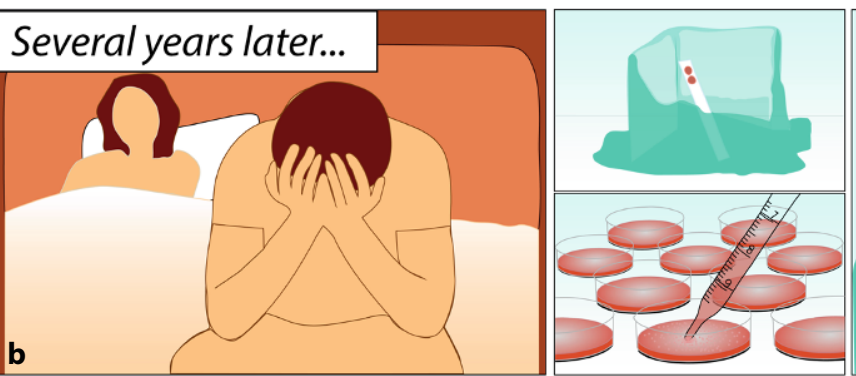

Fig. 1 The life of a male infertile paediatric cancer survivor undergoing SSCT. a Paediatric cancer affects over 400 children (0 to 14 years) each year in the Netherlands and 360,000 worldwide [9]. A proposed therapy to restore fertility is spermatogonial stem cell transplantation (SSCT) which starts with cryopreservation of a testis biopsy prior to the oncologic treatment. Fortunately, cancer treatments have substantially improved in recent years, leading to increased life expectancy. b Years later, severe therapy-related late effects, such as in-

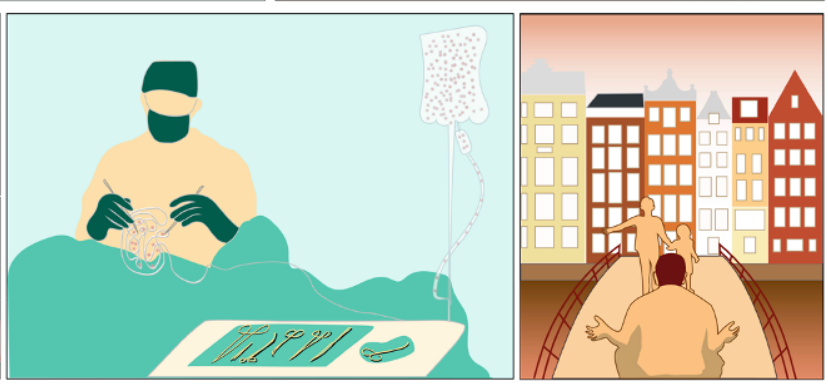

fertility, can affect the quality of life of male childhood cancer survivors. To cure infertility, the cryopreserved testis biopsy can be thawed to start the fertility treatments. In vitro propagation of spermatogonial stem cells (SSCs) is required to increase the number of transplanted cells and the efficiency of the procedure. Upon autotransplantation into the survivor's adult testis, the SSCs repopulate the testes allowing natural conception 
of this method for the recipient and his offspring are also a much needed and pivotal step. In this review we aim to focus on the safety aspect of the key steps of SSCT, which have been studied throughout the last decades and have accelerated the translation of SSCT towards clinical application.

\section{Methods}

After a literature search in PubMed, not restricted to any publishing year, we performed a comprehensive overview of oncofertility topics related to male prepubertal patients. We highlighted significant areas of research related to these patients' fertility preservation and potential cure of fertility focussing on safety of every part of the SSCT process: testicular biopsy, SSC culture, SSC transplantation and offspring generation. We included papers written in English.

\section{Results and discussion}

The aim of SSCT is to fully re-establish fertility in infertile male childhood cancer survivors, allowing longstanding natural conception without resorting to any other fertility treatment [2]. To initiate the SSCT procedure, cryopreservation of a testicular biopsy is offered prior to gonadotoxic treatment. The containing SSCs enable long-term male fertility through a tight balance between self-renewal to maintain the pool of SSCs and differentiation into sperm. In the future, when in case of permanent infertility, the wish for genetically related children cannot be fulfilled by natural conception, a testis biopsy can be thawed. Subsequently, SSCs are propagated in vitro followed by an autologous transplantation back into the testis of the childhood cancer survivor to repopulate the testes and allow natural conception [2]. The safety of SSCT has been studied at multiple biological levels, from the detailed (epi-) genetic analysis of the cells in culture, to large-scale preclinical animal models [10]. Here, we focus on the safety of the technique at multiple levels: from taking the testicular biopsy containing SSCs, to the autotransplantation of the propagated SSCs to restore fertility, and the health of the children conceived after natural conception.

\section{Testis biopsy and cryopreservation}

The first step of SSCT treatment is the collection of testicular tissue by taking testicular biopsies in microsurgical technique prior to gonadotoxic treatment. After taking the medical history, extensive counselling and obtaining informed consent, an ultrasound examination is performed to rule out testicular abnormalities and calculate the volume of the testes. The procedure is performed under general anaesthesia preferably together with another necessary surgery such as implantation of a central line for oncologic treatment or bone marrow aspiration. The surgery is ideally a microsurgical procedure and starts with examination to finally choose the site where the biopsy is taken from (Fig. 2). After performing a funiculus block the scrotal skin is incised, including tunica dartos, then opening of the tunica vaginalis to bring the testis outside the scrotum. Under microscopic control the tunica albuginea will be partially opened on the upper pole of the testis and the biopsy of less than $30 \%$ of the testis is taken, ideally as a wedge so that the remaining tubules and
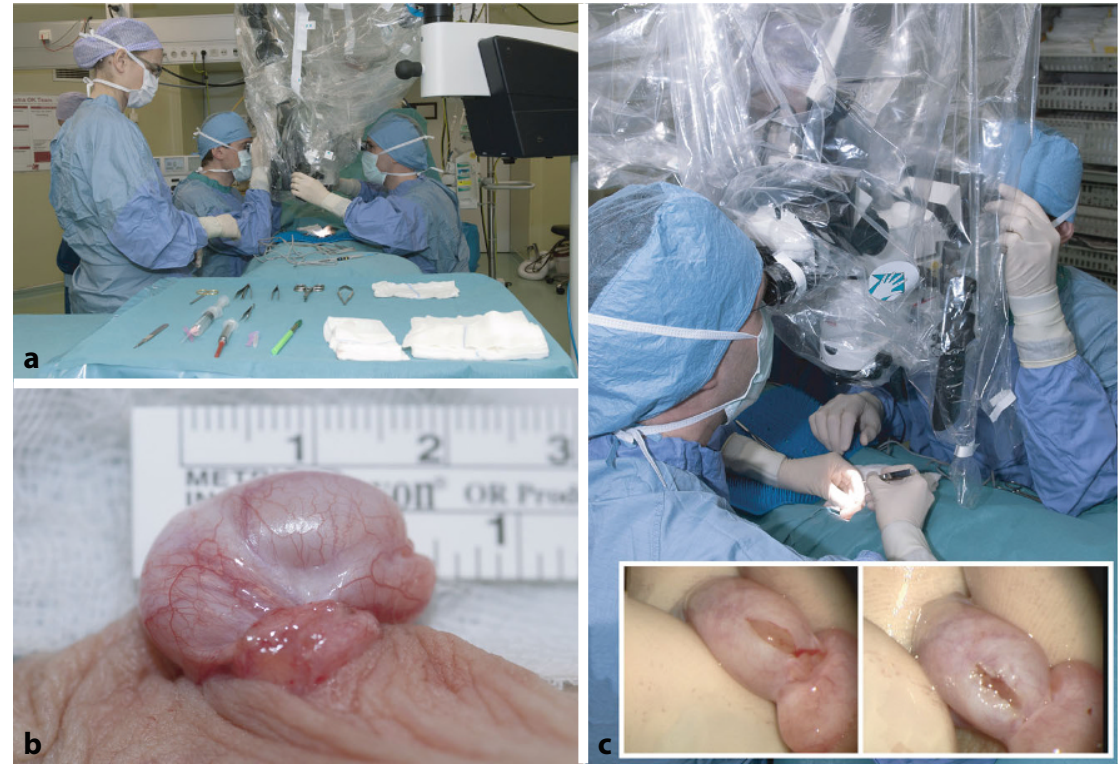

Fig. 2 Microscopic surgical procedure to obtain a testicular biopsy in a prepubertal boy. a Overview of the operation theatre. b Prior to the biopsy, the testis is measured to estimate the biopsy volume. c The biopsy is taken from the upper pole of the testis under microscopic control. Insert: the testis before and after the biopsy (images taken through the microscope). $\mathbf{d}$ and e Closing of the incision of the biopsied testis 
rete testis will remain intact. After the biopsy, meticulous bipolar coagulation is performed before the tunica albuginea is closed with $8 / 0$ absorbable suture material, tunica vaginalis and scrotum will be closed with absorbable material 5/0 analogously [10, 11].

Multiple studies have accessed the post-operative and long-term safety of the biopsy collection in human. Despite all studies reporting some cases of either dermatitis, wound infections, testicular haematomas, or testicular pain, generally, most cohorts found the intervention safe in the short-term [11-13]. In the long-term, studies have also found the biopsy procedure to be safe regarding testicular growth, hormone levels, and reproductive health [10, $11,14,15]$.

Reliable cryopreservation methods also ensure the optimal protection of the reproductive potential by maintaining the health of SSCs within the biopsy [16]. Research has shown that the cryopreservation of the testicular biopsy tissue as a piece is preferable to the cryopreservation of the testicular cell suspension after dissociation of the biopsy as the viability of SSCs is better preserved in testicular biopsies [6]. Biopsy cryopreservation protocols do not only safeguard the viability, longevity, and proliferation rate of the SSCs but also increase their fecundity rate.

\section{Genomic stability of SSCs in culture}

After the patient returns with the desire of genetic offspring and azoospermia is asserted, the biopsy is thawed and SSCs are enriched and propagated in vitro ([17]; Fig. 1). In vitro propagation of SSCs is required to increase the number of transplanted cells for efficient repopulation of the testes after transplantation. The clinical application of SSCT is therefore dependent on the genomic stability of the SSCs during their propagation in culture. The main concern is that in vitro manipulation could affect the (epi-) genetic integrity of these cells and induce a carcinogenic phenotype or adverse health effects on the offspring. Throughout the years, several research groups have investigated possible chromosomal aberrations $[18,19]$, and genetic or epigenetic instability of the SSC cultures in animal studies [18, 20-22] and human in vitro models [19, 23]. Overall, the chromosomal integrity was conserved [18, 19, 23] as well as genomic stability $[19,22]$. However, despite the reassuring epigenetic results in animal SSC cultures [20, 22], some epigenetic alterations were found in imprinted genes after long-term culture of human SSCs [19]. Reassuringly, genome-scale DNA methylation of cultured human SSCs were different from seminomas [23], a severe germ cell cancer arising from SSC precursors. Additionally, no tumours were found in the recipients' testes when uncultured or cultured human SSCs were xeno-transplanted into mouse testes [17, 24] confirming their stability and lack of carcinogenic potential after culture.

\section{Eliminating infiltrated cancer cells from the biopsy}

Another obstacle in using SSCs from a childhood cancer patient's biopsy is the risk of taking infiltrating cancer cells along, thereby reintroducing cancerous cells from the original childhood cancer into the testis of the patient during SSCT. Several studies have investigated ways to remove lingering leukemic cells by cell sorting [25-27]. These methods rely on the differences in expression of cell-surface antigens between malignant cells and SSCs, in order to separate them from each other [26]. Another technique to eliminate leukemic cells from the SSCs is by in vitro propagation of SSCs, as it turns out the leukemic cells cannot survive in the long-term SSC culture system [25]. A few concerns still arise from the above-mentioned protocols. The inherent variability between patients and cultures could lead to leukemic cells remaining in the cell suspension and being transferred back to the patient later. Nonetheless, before SSCT, an aliquot of the cell suspension after propagation is recommended for safety testing (e.g. infectious contamination) [6]. This step could also include a safety check for the presence of original cancer cells [25] or resorting for leukemic cells in order to increase the purity of the SSCs [27]. As SSCT is an elective treatment, ethical concerns may arise with the possibility of causing relapse in recovered cancer patients [26].

\section{Injection of SSCs into the testis}

SSCT was first established and has been extensively studied throughout the years using mouse models [28]. The SSCs are commonly injected in the rete testis via the efferent ducts allowing the cells to travel through the seminiferous tubules and migrate to the basal membrane. However, experiments in larger animals (bovine, monkey) and human cadaver testes, have found that due to anatomical differences, a single injection directly into intratesticular rete testis, guided by ultrasound, was preferable and less invasive $[29,30]$ and confirmed that the transplanted SSCs travel to the basal membrane [31]. Assuring research of autologous and allogeneic transplantation has also been performed in non-human primates that support the clinical translation of SSCT to human [32]. After ultrasound-guided injection of uncultured SSCs into the rete testis of prepubertal rhesus monkeys, $60 \%$ of the recipients demonstrated the presence of mature sperm cells in the ejaculate and ultimately fertilization of these sperm cells with oocytes was achieved via intracytoplasmic sperm injection (ICSI). This experiment in non-human primates demonstrates that SSCT leads to functional donor spermatogenesis.

\section{Safety of SSCT for the recipient}

Hence, apart from preventing reintroduction of cancer cells by transplantation, safeguarding the general 
health of the SSCT recipient is of paramount importance. An extensive study has investigated the safety of the entire SSCT procedure to the adult patient in a mouse model [33]. Busulfan treated mice were transplanted with long-term cultured SSCs and followed up to 18 months of age, equivalent with 60 years in human. Overall, no differences were observed in cancer incidence and lifespan compared between busulfan treated non-transplanted and busulfan treated transplanted mice.

\section{Clinical implications of SSCT to the offspring}

Regrettably, most medically assisted reproductive (MAR) techniques have been introduced to the clinic after preclinical studies focusing on the efficacy but without any systematically and statistically powered preclinical research into the safety of these therapies for the offspring [34]. Although children conceived through current reproductive techniques such as IVF or ICSI are predominantly healthy, there is some evidence of an increased risk of congenital abnormalities, low birthweight, developmental deviations and cardiometabolic disease [35].

Extensive health assessment of the offspring, using animal models, is now commonly required in order to obtain the agreement of medical ethical agencies for releasing novel MAR treatments in a clinical setting [36]. Several studies have provided some information on how SSCT impacts the offspring using rodent models. However, most of these reports have missed parts of the whole SSCT procedure, by use of uncultured SSCs [21] or additional assisted reproductive techniques (ICSI, IVF) to generate offspring [28, 37]. Additionally, other reports have not determined the health of the SSCT offspring $[28,38]$. Therefore, a systematic preclinical follow-up of SSCT offspring development, including all steps of the procedure, was warranted before clinical application [34]. Recently, a preclinical study was performed that thoroughly assessed birth characteristics, childhood development and adult health in SSCT-derived offspring using a systematic approach in a mouse model [39]. This was the first preclinical study that thoroughly investigated a novel MAR. These results indicated that in general, throughout their lifetime, offspring naturally conceived after SSCT does not have increased congenital abnormalities (birthweight and length and physical abnormalities), developmental deviations (reflexes, weight, length, and physical development) and cardiometabolic problems (high blood pressure, altered heart rate, glucose intolerance, obesity) compared to naturally conceived control mice. The incidence of pathologies and life expectancy at the end of the study at 18 months of age (equivalent with 60 years in humans) are also similar between groups. Therefore, culture and autotransplantation of SSCs into sterile males do not seem to impact the health of their offspring throughout life.

\section{Conclusion}

Fertility preservation options are being offered worldwide to male childhood cancer survivors. Despite SSCT still being an experimental procedure, promising strides are being made towards the advancement of this therapy to clinic. SSCT would be the first fertility therapy to effectively cure male infertility. Currently, one of the main safety hurdles to be surpassed is the risk of reintroducing malignant cells into the adult recovered childhood cancer survivor. Additionally, as the small size of the testis biopsy contains a limited amount of SSCs, the required propagation of these cells in vitro could result in some epigenetic changes in the cells. However, these potential epigenetic changes do not seem to affect the general health of the offspring. With the tremendous progress of SSCT in recent years, childhood cancer survivors from solid tumours and non-malignant hematologic patients (i.e., sickle cell anaemia, thalassemia) are both great candidates for SSCT in a first clinical trial with long term follow up of the offspring's health. Ultimately, SSCT could guarantee a fertile future for prepubertal patients after gonadotoxic treatments.

Open Access This article is distributed under the terms of the Creative Commons Attribution 4.0 International License (http://creativecommons.org/licenses/by/4.0/), which permits unrestricted use, distribution, and reproduction in any medium, provided you give appropriate credit to the original author(s) and the source, provide a link to the Creative Commons license, and indicate if changes were made.

\section{References}

1. Poganitsch-Korhonen M, Masliukaite I, Nurmio M, et al. Decreased spermatogonial quantity in prepubertal boys with leukaemia treated with alkylating agents. Leukemia. 2017;31:1460-3.

2. Goossens E, Jahnukainen K, MitchellR, etal. Fertility preservation in boys: recent developments and newinsights. Hum Reprod Open. 2020;2020:1-18.

3. Mulder RL, Font-Gonzalez A, Green DM, et al. Fertility preservation for male patients with childhood, adolescent, and young adult cancer: recommendations from the pancareLIFE consortium and the international late effects of childhood cancer guideline harmonization group. LancetOncol. 2021;22:e57-67.

4. Integrated Kankercentra Nederland. Cancer incidence in The Netherlands between 1989-2020. 2021.

5. CBS. Childhood cancer mortality further down. 2018. https://cbs.nl. Accessed28 Sept2021.

6. Onofre J, KadamP, BaertY, etal. Testicular tissue cryopreservation is the preferred method to preserve spermatogonial stem cells prior to transplantation. Reprod Biomed Online. 2020;40:261-9.

7. Kanatsu-Shinohara M, Miki H, Inoue K, et al. Long-term culture of mouse male germline stem cells under serum-or feeder-free conditions. Biol Reprod. 2005;72:985-91.

8. Lei Q, LaiX, Eliveld J, et al. In vitro meiosis of male germline stem cells. Stem Cell Reports. 2020;15:1140-53. 
9. Johnston WT, Erdmann F, Newton R, et al. Childhood cancer: estimating regional and global incidence. Cancer Epidemiol. 2021;71:101662.

10. Wyns C, Kanbar M, Giudice MG, et al. Fertility preservation for prepubertal boys: lessons learned from the past and update on remaining challenges towards clinical translation. Hum Reprod Update. 2021;27:433-59.

11. Uijldert M, Meißner A, de Melker AA, et al. Development of the testis in pre-pubertal boys with cancer after biopsy for fertility preservation. Hum Reprod. 2017;32:2366-72.

12. Wyns C, Curaba M, Petit S, et al. Management of fertility preservation in prepubertal patients: 5 years' experience at the catholic university of Louvain. Hum Reprod. 2011;26:737-47.

13. Ginsberg JP, Li Y, Carlson CA, et al. Testicular tissue cryopreservation in prepubertal male children: an analysis of parental decision-making. Pediatr Blood Cancer. 2014:61:1673-8.

14. BorgströmB, Fridström M, Gustafsson B, etal. Aprospective study on the long-term outcome of prepubertal and pubertal boys undergoing testicular biopsy for fertility preservation prior to hematologic stem cell transplantation. Pediatr Blood Cancer. 2020;67:1-11.

15. Kanbar M, de Michele F, Giudice MG, et al. Long-term follow-up of boys who have undergone a testicular biopsy for fertility preservation. Hum Reprod. 2021;36:26-39.

16. OnofreJ, BaertY, Faes K, et al. Cryopreservation of testicular tissue or testicular cell suspensions: a pivotal step in fertility preservation. Hum Reprod Update. 2016;22:744-61.

17. Sadri-Ardekani H, MizrakSC, van Daalen SKM, et al. Propagation of human spermatogonial stem cells in vitro. JAMA. 2009;302:2127-34.

18. Goossens E, de Vos P, Tournaye H. Array comparative genomic hybridization analysis does not show genetic alterations in spermatozoa and offspring generated after spermatogonial stem cell transplantation in the mouse. Hum Reprod. 2010;25:1836-42.

19. Nickkholgh B, MizrakSC, vanDaalenSKM, etal. Geneticand epigenetic stability of human spermatogonial stem cells duringlong-term culture. Fertil Steril. 2014;102:1700-7.

20. Langenstroth-Röwer D, Gromoll J, Wistuba J, et al. De novo methylation in male germ cells of the common marmoset monkey occurs during postnatal development and is maintained in vitro. Epigenetics. 2017;12:527-39.

21. Goossens E, De Rycke M, Haentjens P, et al. DNA methylation patterns of spermatozoa and two generations of offspring obtained after murine spermatogonial stem cell transplantation. Hum Reprod. 2009;24:2255-63.

22. Kanatsu-Shinohara M, Ogonuki N, Iwano T, et al. Genetic and epigenetic properties of mouse male germline stem cells during long-term culture. Development. 2005;132:4155-63.

23. Struijk RB, Dorssers LCJ, Henneman P, et al. Comparing genome-scale DNA methylation and CNV marks between adult human cultured ITGA6+ testicular cells and seminomas to assess in vitro genomic stability. PLoS ONE. 2020;15:1-18.

24. Nagano M, Patrizio P, Brinster RL. Long-term survival of human spermatogonial stem cells in mouse testes. Fertil Steril. 2002;78:1225-33.

25. Sadri-Ardekani H, Homburg $\mathrm{CH}$, van Capel TM, et al. Eliminating acute lymphoblastic leukemia cells from human testicular cell cultures: a pilot study. Fertil Steril. 2014;101:1072-1078.e1.
26. Dovey SL, Valli H, Hermann BP, et al. Eliminating malignant contamination from therapeutic human spermatogonial stem cells. JClin Invest. 2013;123:1833-43.

27. Hermann BP, Sukhwani M, Salati J, et al. Separating spermatogonia from cancer cells in contaminated prepubertal primate testis cell suspensions. Hum Reprod. 2011;26:3222-31.

28. Kanatsu-Shinohara M, OgonukiN, InoueK, etal. Long-term proliferationincultureandgermlinetransmission ofmouse male germline stem cells. Biol Reprod. 2003;69:612-6.

29. SchlattS, Rosiepen G, Weinbauer GF, etal. Germ cell transfer into rat, bovine, monkey and human testes. Hum Reprod. 1999;14:144-50.

30. Ning L, Meng J, Goossens E, et al. In search of an efficient injection technique for future clinical application of spermatogonial stem cell transplantation: infusion of contrast dyes in isolated cadaveric human testes. Fertil Steril. 2012;98:1443-8.

31. Faes K, Tournaye H, Goethals L, et al. Testicular cell transplantation into the human testes. Fertil Steril. 2013;100(4):981-8.

32. Hermann BP, Sukhwani M, Winkler F, et al. Spermatogonial stem cell transplantation into rhesus testes regenerates spermatogenesis producing functional sperm. Cell Stem Cell. 2012;11:715-26.

33. Mulder CL, Catsburg LAE, Zheng Y, et al. Long-term health in recipients of transplanted in vitro propagated spermatogonial stem cells. Hum Reprod. 2018;33:81-90.

34. Mulder CL, Serrano JB, Catsburg LAE, et al. A practical blueprint to systematically study life-long health consequences of novel medically assisted reproductive treatments. Hum Reprod. 2018;33:784-92.

35. Saatci D, Sutcliffe AG. Children of ART. In: Sharif K, Coomarasamy A, editors. Assisted reproduction techniques: challenges and management options. 2nd ed. New York: Wiley; 2021.pp. 658-63.

36. Pennings LG, de Wert G, Shenfield F, et al. ESHRE task force on ethics and law 13: the welfare of the child in medically assisted reproduction. Hum Reprod. 2007;22:2585-8.

37. Wu X, Goodyear SM, Abramowitz LK, et al. Fertile offspring derived from mouse spermatogonial stem cells cryopreserved for more than 14 years. Hum Reprod. 2012;27:1249-59.

38. Ryu B-Y, Orwig KE, Oatley JM, et al. Efficient generation of transgenic rats through the male germline using lentiviral transduction and transplantation of spermatogonial stem cells. J Androl. 2007;28:353-60.

39. Serrano JB, van Eekelen R, de Winter-Korver CM, et al. Impact of restoring male fertility with transplantation of in vitro propagated spermatogonial stem cells on the health of their offspring throughout life. Clin Transl Med. 2021;11(10):e531.

Joana B. Serrano, MSc, biomedical scientist, $\mathrm{PhD}$ candidate

Dr. Andreas Meißner, urologist, clinical andrologist (EAA), FEBU

Prof. Dr. Ans M.M. van Pelt, stem cell biologist, Professor Translational Reproductive Biology

Dr. Callista L. Mulder, reproductive biologist, Researche Associate 